http://dx.doi.org/10.7197/1305-0028.13903

\title{
Vitamin D deficiency in children in Aegean Region in Turkey
}

\section{Türkiye'de Ege Bölgesi'ndeki çocuklarda D vitamini eksikliği}

\author{
*Neşe Doğan ${ }^{1}$, Ayfer Aydoğdu Çolak ${ }^{1}$, Necmiye Güden ${ }^{1}$, Füsun Üstüner ${ }^{1}$ \\ ${ }^{1}$ İzmir Tepecik Education and Research Hospital \\ Corresponding author: Dr. Neșe Doğan, Biyokimya Bölümü, Tepecik Eğitim ve Araștırma Hastanesi, \\ TR-35120, İzmir. \\ E-mail: drnesesimsek@gmail.com \\ Received/Accepted: April 14, 2014/January 28, 2015 \\ Conflict of interest: None declared.
}

\section{SUMMARY}

Objective: Although vitamin D deficiency have been suggested in children is widespread recently, the data about vitamin D status of Turkish children is limited. The objective of the present study was to determine prevalence of vitamin D deficiency in children in Aegean region and to show effect of age, gender and seasons on vitamin D levels. The data from hospital information system was examined retrospectively.

Method: Between January 2011 and February 2013, children admitted to department of paediatrics our hospital for health examination was taken blood for vitamin D measurement. Serum vitamin D levels were determined by electrochemiluminescent method and categorized as $<20 \mathrm{ng} / \mathrm{mL}$ is deficiency and $<30 \mathrm{ng} / \mathrm{mL}$ is insufficiency.

Results: A total of 2909 children aged 1 month to 17 years participated in this retrospective study. All the subjects were divided into subgroups according to their age: 0-3 years old, 4-6 years old, 712 years old and 13-17 years old representing infancy and toddler, preschool, school age and adolescence stages respectively. The highest mean level of serum vitamin D was found in the 0-3 years old stage and the lowest one was found in 13-17 years old stage.

Conclusion: In Turkish children, the prevalence of vitamin D deficiency and insufficiency $(61 \%)$ is considerable size. We suggest that the recommendation for vitamin D supplementation after the first year of life could be beneficial especially for school children and adolescents.

Keywords: Vitamin D deficiency, vitamin D insufficiency, children, season

\section{ÖZET}

Amaç: Tüm dünyada D vitamin eksikliği çocuk, genç yetişkin ve yaşlilarda çok fazla araştırılmasına rağmen ülkemizdeki çocuk ve adolesan grup ile ilgili veriler sınırlıdır. Hastanemizde D vitamini ölçümü yapılan çocuklarda D vitamini eksikliği prevelansını belirlemeyi; yaş, cinsiyet ve mevsimlerin etkisini görmeyi amaçladık.

Yöntem: Hastanemize sağlık kontrolü için Ocak 2011-Şubat 2013 tarihleri arasında başvuran ve vitamin D (25-OH) ölçümleri yapılan 2909 çocuğun vitamin D düzeyleri hastane bilgi sisteminden retrospektif olarak incelendi. D vitamini durumları, vitamin D düzeyleri $20 \mathrm{ng} / \mathrm{mL}$ 'den düşük ise eksiklik; $30 \mathrm{ng} / \mathrm{mL}$ ise yetersizlik olarak sınıflandırıldı. Ayrıca yaşlarına göre çocuklar 0-3 yaş, 4-6 yaş, 7-12 yaş ve 13-17 yaş olarak dört alt gruba bölündü.

Bulgular: Tüm çocukların (1653 erkek, 1256 kız) vitamin D sonuçları ortalaması 28,00 $\pm 15,55$ $\mathrm{ng} / \mathrm{mL}$ bulundu.En yüksek serum D vitamini 0-3 yaş grubunda ve en düşük düzey 13-17 yaş grubunda bulundu. Kız ve erkek çocuklarda mevsimler arasında D vitamini ölçümlerinde anlamlı fark saptand1. Tüm yaş gruplarında D vitamini eksikliği yüksek oranda bulundu.

Sonuç: İncelediğimiz tüm çocukların yaklaşık \%61'inin D vitamini yetersizliği ve eksikliğinin bulunması, yaşamın ilk yılında sağlık politikasında da yer alan D vitamini desteğinin daha sonraki yaşlarda ve özellikle adolesan dönemde devam ettirilmesinin uygun olacağı düşünüldü.

Anahtar sözcükler: D vitamini eksikliği, D vitamini yetersizliği, çocuklar, mevsim 


\section{INTRODUCTION}

Vitamin D is a steroid hormone which regulate mainly calcium and phosphorus metabolism. There is two nature vitamin D source. The main source is cutaneous synthesis after exposure to sunlight ${ }^{1}$. Second but limited nature source is taking from the diet such as especially fish oil, eggs and liver. Also human get this vitamin from fortified dairy products such as milk and some orange juices, yogurts and cereals are fortified with vitamin D3 or vitamin D supplements ${ }^{2}$. Solar ultraviolet B radiation penetrates the skin and converts 7dehydrocholesterol to previtamin D3, which is rapidly converted to vitamin D3. Vitamin D from the skin and diet is metabolized in the liver to 25-hydroxyvitamin D. The 25-hydroxyvitamin $\mathrm{D}$ is metabolized in the kidneys by the enzyme $1 \alpha$ - hydroxylase to its active form, 1.25dihydroxyvitamin D.

The plasma parathyroid hormone levels and serum calcium and phosphorus levels regulate this form's production. The active form, 1.25-dihydroxyvitamin D markedly increases the efficiency of intestinal calcium and phosphorus absorption ${ }^{3}$.

The enzyme 24-hydroxylase catabolizes both 25-hydroxyvitamin $\mathrm{D}$ and 1.25dihydroxyvitamin $\mathrm{D}$ into biologically inactive, water-soluble calcitroic acid ${ }^{4}$.

Vitamin D is one of the most researched issues about, recently. At lots of points as its metabolism, symptoms of deficiency, therapeutic dosages, sources of vitamin D, prevalence of vitamin $\mathrm{D}$ deficiency was researched. The reason of this attractive is that is seen,vitamin D play a role in the ethology of some cancers, multiple sclerosis, Type 1 diabetes, Crohn diseases, autoimmune diseases and granulmatous diseases as tuberculosis 5. Reference value was considered, treatment scheme was made, health politics were developed. Despite numerous preventive strategies, vitamin D deficiency has remained a global health problem among children and adolescent. Not only undeveloped countries, it is also developed countries' problem such as Canada, Australia, the United Kingdom and the United States.
İzmir is located in a mostly sunny region, situated at a latitude of north 38.30, mean sunny hours in a day is very high. Even in winter at least 4 hours sunshine reaches the ground, neverthless in summer it raises to twelwe hours in a day ${ }^{6}$.

In Turkey, exposure to sunlight represents the main source of vitamin $D$. The remained part of the total vitamin $\mathrm{D}$ comes from dietary intake. At first-aged children there is other souce which is vitamin D supplement which is a free vitamin D supplementation campaign nationwide of the Ministry of Health in Turkey. Fortified food with vitamin $\mathrm{D}$ is negligible in Turkey. The prevalence of vitamin D deficiency is considerable size is seen in our country $^{7}$ as overall the world. The objective of the present study was to determine prevalence of vitamin D deficiency in children whose serum vitamin $\mathrm{D}$ levels measured in our laboratory and to show effect of age, gender and seasons on vitamin D levels.

\section{MATERIAL AND METHODS}

Vitamin D levels of children patients, who admitted our hospital between January 2011 and February 2013, were investigated retrospectively through the hospital information system. Our hospital is a tertiary Education and Researching Hospital which serves a large area, not only our city and also the neighbour cities in Aegean region in Turkey. A total of 2909 children, who aged 1 month to 17 years, participated in this study. All the subjects were divided into subgroups according to their age: 0-3 years which is represent the infancy and toddler stage, 4-6 years which is represent the preschool stage, 7-12 years which is represent the school age stage and 13-17 years which is represent the adolescence stages. Serum vitamin D levels were measured at same day with venipuncture at Cobas E 411 (Roche Diagnostics) using an electrochemiluminescent method (ECLIA) by using original reagent, control materials and calibrator. Measured vitamin D is total vitamin $\mathrm{D}$. The intra-assay and inter-assay CVs were $3.7 \%$ and $2.9 \%$ respectively. The lower detection limit of the assay was $3 \mathrm{ng} / \mathrm{mL}$. 
Here are the generally accepted cut off points for measurements of vitamin $D$, Vitamin D deficiency is below $20 \mathrm{ng} / \mathrm{mL}$, Vitamin D insufficiency is below 30 $\mathrm{ng} / \mathrm{mL}^{8,9}$.

March, April, May was conducted as spring; June, July, August was conducted as summer; September, October, November was conducted as autumn; December, January, February was conducted as winter.

All analyses were performed by using SPSS software (version 15.0, SPSS Inc., Chicago, IL). For all data sets, the Kolmogorov-Smirnov test of normality was used to determine whether the distribution of values was normal $(p>0.05)$ or not normal $(\mathrm{p}<0.05)$ and to indicate whether parametric or nonparametric statistical analysis should be used to analyse test results. None-normally distributed data would be analysed by the Wilcoxon's rank sum test,

Table 1: The mean vitamin D levels, the prevelence of deficiency and insufficiency according to genders and seasons.

\begin{tabular}{l|c|ccc}
\hline & $\mathbf{n}$ & The mean vitamin D $(\mathbf{n g} / \mathbf{m L})$ & Vitamin D deficiency $(\%)$ & Vitamin D insufficiency $(\%)$ \\
\hline Boys & 1653 & $27.88 \pm 15.15$ & 35.3 & 62.4 \\
Girls & 1256 & $28.16 \pm 16.05$ & 35.0 & 59.6 \\
Summer & 559 & $31.70 \pm 16.04$ & 31.3 & 58.0 \\
Autumn & 646 & $26.64 \pm 14.65$ & 42.6 & 66.9 \\
Winter & 1091 & $25.77 \pm 15.40$ & 38.2 & 64.6 \\
Spring & 613 & $29.24 \pm 16.05$ & 25.3 & 52.4 \\
\hline
\end{tabular}

When looked the difference between genders at four season, there is no significant difference. In summer, the mean serum vitamin D level was $28.80 \pm$ $16.09 \mathrm{ng} / \mathrm{mL}$ in boys; the mean serum vitamin D level was $29.73 \pm 16.01 \mathrm{ng} / \mathrm{mL}$ in girls (p: 0.49). In autumn, the mean serum vitamin $\mathrm{D}$ level was $25.71 \pm 15.52$ $\mathrm{ng} / \mathrm{mL}$ in boys; the mean serum vitamin $\mathrm{D}$ and normally distributed data would be analysed using two-tailed independent samples t test. Differences among three or more mean values were evaluated with One-Way ANOVA analysis of variance. Descriptive results are expressed as percentages, mean and standard deviations (SD), and minimum to maximum values as appropriate. Rates and 95\% confidence intervals are presented for the pooled results. Differences were considered significant if $\mathrm{p}<0.05$.

This study is a monocentric and retrospective study.

\section{RESULTS}

The final data was composed of 2909 children (1653 boys; 1256 girls), aged between 0 and 17 years old $(5.7 \pm 5.6)$. The mean serum vitamin $\mathrm{D}$ of the whole group was $28.00 \pm 15.55$ (3.00-93.49) ng/mL.

level was $25.84 \pm 15.27 \mathrm{ng} / \mathrm{mL}$ in girls (p: 0.92). In winter, the mean serum vitamin $D$ level was $26.10 \pm 13.72 \mathrm{ng} / \mathrm{mL}$ in boys; the mean serum vitamin D level was $27.42 \pm$ $15.87 \mathrm{ng} / \mathrm{mL}$ in girls (p: 0.14). In spring, the mean serum vitamin D level was 32.65 $\pm 15.36 \mathrm{ng} / \mathrm{mL}$ in boys; the mean serum vitamin D level was $30.41 \pm 16.84 \mathrm{ng} / \mathrm{mL}$ in girls (p: 0.09).

Table 2: Distribution of the prevalence of vitamin $D$ deficiency according to the season at four stages

\begin{tabular}{l|cccc}
\hline \multirow{2}{*}{} & \multicolumn{4}{|c}{ The prevelence of vitamin D deficiency $(\%)$} \\
\cline { 2 - 5 } & The infancy and toddler & The preschool & The school & The adolescence \\
\hline Spring & $(\mathbf{n = 2 9 2 )}$ & $(\mathbf{n = 9 1 )}$ & $(\mathbf{n = 3 0 4 )}$ & $(\mathbf{n = 3 3 5 )}$ \\
Summer & 12.7 & 14.3 & 14.8 & 17.9 \\
Autumn & 13.4 & 12.1 & 18.8 & 20.3 \\
Winter & 28.8 & 26.4 & 28.0 & 24.5 \\
& 45.2 & 47.3 & 38.5 & 37.3 \\
\hline
\end{tabular}


Table3: Genders mean vitamin D values, the prevalence of deficiency and insufficiency at four different stage.

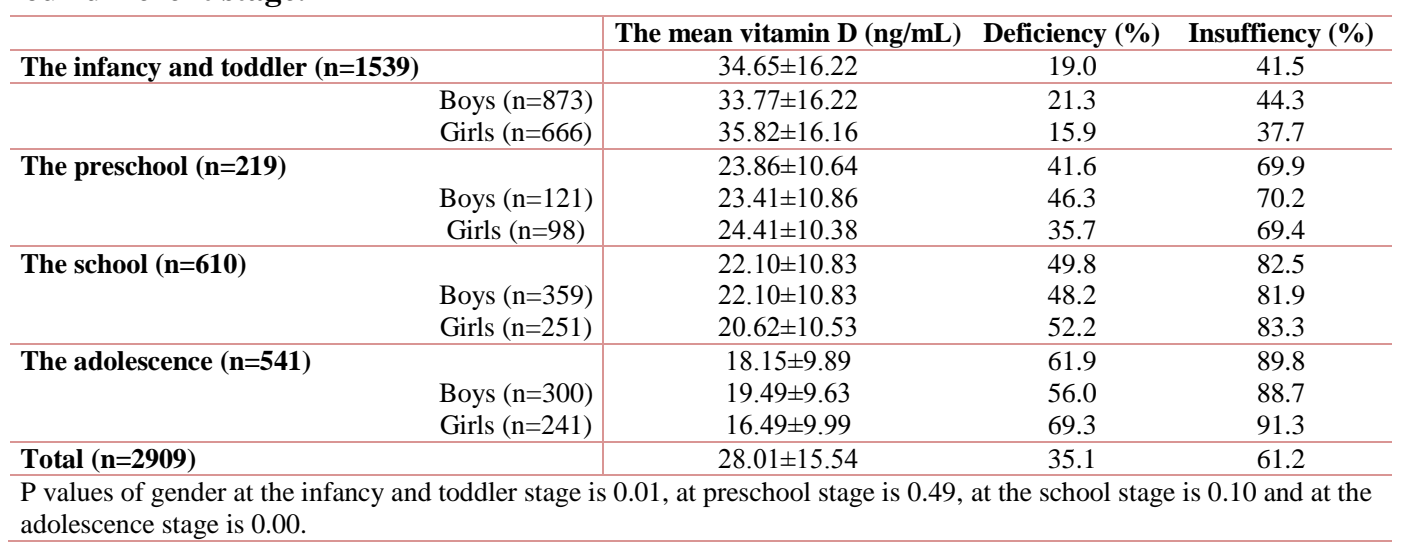

\section{DISCUSSION}

The main source of vitamin $D$ is cutaneous synthesis by the ultraviolet B rays way. A severe vitamin $\mathrm{D}$ deficiency could be reason of hypocalcaemia, bone fractures, bone deformities, rickets, and osteomalacia ${ }^{10}$. If this source is limited because of different reasons as wearing style, sun block, season, skin colour, vitamin $\mathrm{D}$ should receive through the intake of supplements and foods. In some developed countries, commercial fluid dairyproducts (excluding yogurt drinks) are fortified with vitamin D through regulated public health policy in accordance with published guidelines. It has recommended human milk is the ideal nutrition source in the first year of babies. But it has not enough vitamin D to satisfy infant's requirement. It has recommended that infants and children should receive $400 \mathrm{IU}$ of vitamin D per day through diet or supplementation ${ }^{11}$. Vitamin D levels were investigated in several studies conducted also in Turkey, especially in pregnant mothers and their babies' studies have shown a high rate of vitamin D deficiency $^{12-14}$. The Turkey Ministry of Health has also issued guidelines for a uniform dose of vitamin D $400 \mathrm{IU} /$ day for all infants during their first year of life. There are no recommendations for vitamin D supplementations beyond 1 year. In our study investigated Vitamin D levels in children who's Vitamin D measured in our laboratory, the average vitamin $\mathrm{D}$ levels were found below $30 \mathrm{ng} / \mathrm{mL}$. For vitamin D insufficiency when cut off point is accepted as $30 \mathrm{ng} / \mathrm{mL}$, prevalence of insufficiency was $61 \%(n=1.781)$. For vitamin $D$ deficiency when cut off point is accepted as $20 \mathrm{ng} / \mathrm{mL}$, prevalence of deficiency was $35 \%(\mathrm{n}=1.023)$. In this study, the prevalence of vitamin D insufficiency $(<30$ $\mathrm{ng} / \mathrm{mL}$ ) of $0-3$ age group data is similar to findings from Gordon and colleagues study of 0-2 age group in America were found was $40 \%$. Breastfeeding was associated with risk of vitamin D deficiency ${ }^{15}$. In this age group the prevalence of sufficiency was $58 \%$, but by age older the prevalence of sufficiency becomes lower. In adolescence stage (13-17 years) only $10 \%$ of children had sufficient vitamin D. In other study conducted in America and New Zealand, the prevalence of vitamin D insufficiency $(<30 \mathrm{ng} / \mathrm{mL})$ in adolescence age group higher than in early age groups were shown ${ }^{16,17}$.

Saintonge and colleagues studied in adolescent population (13-17 years) in America boys could intake more vitamin D from food than girls so boys could receive higher vitamin D levels18. Contrast in our study, in the same age group vitamin D level is higher girls seen. However the prevalence of vitamin D deficiency in boys was D $89 \%$; in girls $91 \%$, these were still very high.

The another study in which is searched season effects, study in Estonia which was based on random society, at the end of the summer, vitamin D levels were higher in both genders to winter ${ }^{18}$. This is similar to our study vitamin D levels higher in summer measurements than winter's.

Vitamin D status in childhood and adolescence may play a role in the prevention of 
osteoporosis. Even adequate status may reduce the adult risk of diabetes, ischaemic heart disease, hypertension and tuberculo$\operatorname{sis}^{19}$. On the other hand because of the relation of sun exposure to skin cancer, public has been awarded about sunlight exposure and the risks of various skin cancers. Moreover, it has recommended that infants younger than 6 month not be exposed to the sun and that all children and adolescents use sunscreens and clothing to protect them from ultraviolet $\mathrm{B}$ radiation exposure and to prevent skin cancer ${ }^{20}$. This recommendation is useful for protected from a bad survey cancer as skin cancer but this situation makes the vitamin D deficiency come. At the last risk of some diseases known relationship between vitamin D deficiency and some cancers, multiple sclerosis, type 1 diabetes, Crohn diseases, autoimmune diseases and infection diseases as tuberculosis may able to increase.

In conclusion; the prevalence of vitamin D deficiency and insufficiency among children in Aegean Region in Turkey is high, especially in adolescent's stage. We recommend that all children and adolescents should have vitamin D supplementation also after the first year of life. The government must develop public policies for the fortification of milk, milk products, and fruit juices with vitamin $D$ for providing sufficient levels to a healthy future.

\section{REFERENCES}

1. Harris SS, Dawson-Hughes B. Seasonal changes in plasma 25hydroxyvitamin D concentrations of young American black and white women. Am J Clin Nutr 1998; 67: 1232-6.

2. Holick MF. Vitamin D Deficiency. N Eng J Med 2007; 357: 266-81.

3. Heaney RP, Dowell MS, Hale CA, Bendich A. Calcium absorption varies within the reference range for serum 25-hydroxyvitamin D. J Am Coll Nutr 2003; 22: 142-6.

4. Searing D, Leung D YM. Vitamin $\mathrm{D}$ in atopic dermatitis, asthma and allergic diseases. Immunol Allergy Clin North Am 2010; 30: 397-409.

5. White J. Vitamin D Signaling, In- fectious Diseases, and Regulation of Innate Immunity. Infection and Immunity 2008; 3837-43.

6. Obtained from http: //www. dmi. gov. tr. Date of access: 10. 03. 2015.

7. Yildiz O, Colak AA, Coker I,Turkon H. Vitamin D correlation between mother and baby during pregnancy in the winter. Turk $\mathbf{J}$ Biochem 2012; 37: 146-9.

8. Vieth R. Why the minimum desirable serum 25 hydroxyvitamin D level should be $75 \mathrm{nmol} / \mathrm{L}$. Best Pract Res Clin Endocrinol Metab 2011; 25: 681-91.

9. Ward LM, Gaboury I, Ladhani M, Zlotkin S. Vitamin D-deficiency rickets among children in Canada. CMAJ 2007; 177: 161-6.

10. McGillivray G, Skull AS, Davie G, Kofoed SE, Frydenberg A, Rice J, Cooke R, Carapeti JR. High prevalence of asymptomatic vitamin $\mathrm{D}$ and iron deficiency in East African immigrant children and adolescents living in a temperate climate, Arch Dis Child 2007; 92: 1088-93.

11. Akman AO, Tumer L, Hasanoğlu A, İlhan M, Cayc1 B. The frequency of vitamin $D$ insufficiency in healthy children between 1 and 16 years of age in Turkey. Pediatr Int 2011; 53: 968-73.

12. Hatun S, Islam O, Cizmecioglu F, Kara B, Babaoglu K, Berk F. Subclinical vitamin $\mathrm{D}$ deficiency is increased in adolescent girls who wear concealing clothing. J Nutr 2005; 135: 218-22.

13. Halicioglu O, Aksit S, Koc F, Akman SA, Albudak E, Yaprak I. Vitamin D deficiency in pregnant women and their neonates in spring time in western Turkey. Paediatr Perinat Epidemiol 2012; 26: 53-60.

14. Gordon CM, Feldman HA, Sinclair L, Williams AL, Kleinman PK, Rossello H.P. Prevalence of Vitamin D Deficiency Among Healthy Infants and Toddlers. Arch Pediatr Adolesc Med 2008; 162: 505-12.

15. Moore C, Murphy MM, Keast DR, Holick MF. Vitamin D intake in 
the United States. J Am Diet Assoc 2004; 104: 980-3.

16. Rockell JE, Green TJ, Skeaff CM, Whiting SJ, Taylor RW, Williams SM. Season and ethnicity are determinants of serum 25hydroxyvitamin $\mathrm{D}$ concentrations in New Zealand children aged 514 years. J Nutr 2005; 135: 26028.

17. Saintonge S, Bang H, Gerber LM. Implications of a new definition of vitamin $\mathrm{D}$ deficiency in a multiracial us adolescent population: The National Health and Nutrition Examination Survey III. Pediatrics 2009; 123: 797-803.

18. Kull M, Kallikorm R, Tamm A, Lember M. Seasonal variance of $25-(\mathrm{OH})$ vitamin $\mathrm{D}$ in the general population of Estonia, a Northern European country. BMC Public Health 2009; 9: 22.

19. Liang L, Chantry C, Styne DM, Stephensen CB. Prevalence and risk factors for vitamin $\mathrm{D}$ deficiency among healthy infants and young children in Sacramento, California. Eur J Pediatr 2010; 169: 1337-44.

20. American Academy of Pediatrics, Committee on Environmental Health.Ultraviolet light: A hazard to children. Pediatrics 1999; 104: 328-33. 